\title{
Capital Adequacy Regulation and Financial Distress Resolution in the Nigerian Banking Industry: An ARDL Approach
}

\author{
Adolphus Joseph Toby, Jibaniya Katon Danjuma \\ Department of Banking and Finance, Rivers State University, Port Harcourt, Nigeria \\ Email address: \\ toby.adolphus@ust.edu.ng (A. J. Toby) \\ To cite this article: \\ Adolphus Joseph Toby, Jibaniya Katon Danjuma. Capital Adequacy Regulation and Financial Distress Resolution in the Nigerian Banking \\ Industry: An ARDL Approach. International Journal of Finance and Banking Research. Vol. 7, No. 4, 2021, pp. 95-100. \\ doi: $10.11648 /$ j.ijfbr.20210704.12
}

Received: June 21, 2021; Accepted: August 24, 2021; Published: September 10, 2021

\begin{abstract}
This paper investigates the impact of capital adequacy regulation on financial distress resolution in the Nigerian banking industry within the ARDL framework using aggregate time series data. Financial distress resolution is measured by ratio of distressed banks, while capital adequacy regulation is measured by credit to risk weighted assets ratio, capital to total assets ratio and assets to capital ratio. The sample comprises annual time series data covering the period from 1986 to 2018 , while the data are obtained from three reliable sources: namely, Central Bank of Nigeria (CBN) statistical bulletin, Nigeria Deposit Insurance Corporation (NDIC) quarterly and Nigeria Stock Exchange (NSE) fact sheet. The plausible ARDL specification is determined using the Schwarz information criterion, which selects a model with two lagged values of ratio of distressed banks as additional explanatory variables. We find that financial distress resolution exhibits persistence behavior and depends on its two lagged values, but with a positive and sizable net own effect. However, the relationship between financial distressed resolution and capital adequacy regulation measures has no lagged effect. Also, both the individual and joint impacts of the three capital adequacy regulation ratios are not statistically significant. Based on these findings, we conclude that capital adequacy regulation is not an important determinant of financial distress resolution in Nigeria, and that the regime of riskbased capital regulation may produce further moral hazards behavior in the Nigerian banking sector.
\end{abstract}

Keywords: Financial Distress Resolution, Capital Adequacy Regulation, ARDL

\section{Introduction}

Bank distress connotes "unhealthy situation" or a state of inability and weakness which constraints the attainment of set goals and targets by the bank. It can also be described as a situation "of complete or near loss of shareholders' funds" [18]. A financial institution, be it a bank, a finance company or insurance company is assumed to be viable, healthy, and free from distress "as long as it can meet all its obligations out of income over the long run" [12].

Banks fail either because of illiquidity or capital inadequacy, or both. A typology of problem banks is as stated: illiquid but solvent, insolvent but liquid, illiquid and insolvent. Capital plays a crucial role, which include providing cushion for absorbing operational loses, measure of shareholder's confidence and stake in the bank. It reveals the banks' ability to finance the capital expenditure and fixed asset; and provides protection to depositors' funds among others.

Since the first owner of gold deposit discovered that profits could be made by lending some of gold deposited for safe keeping, there has been a concern for the 'Capital Adequacy' of depository institutions. The idea is simple enough, if the value of an institution's assets may fall in the future, its deposit will generally be impacted, the larger the current value of assets in connection with the value of deposits. Defining capital as the difference between assets and deposits, the larger the ratio of capital to assets, (or the ratio of capital to deposits) the safer the deposits. Accordingly, Sharpe [19] posit that at some level, capital will be "adequate," that is, the deposit will be safe (Depository institutions are regulated and examined by regulatory authorities and much of this effort is directed toward ensuring capital adequacy. Adequate capital is particularly essential for any business and banking is not left out. 
The commercial banks in Nigeria have recently been restructured into Regional, National and International banks with paid-up share capital of $\$ 10$ billion, $\$ 25$ billion and $\$ 50$ billion respectively. The ratio of adjusted capital to loan assets of a bank should not be more than 1: 10, in other words, a naira capital should support not more than N10 of loans. Banks with risk weighted asset ratio above 10 percent are classified as adequately capitalized; a bank with a negative RWA ratio is categorized as technically insolvent. This classification is done in an attempt at establishing standard for effective supervisory intervention [2]. The classifications according to NDIC are adequately capitalized, marginally undercapitalized, significantly undercapitalized, critically undercapitalized or technically insolvent.

The purpose of this study is to examine the impact of capital adequacy regulation on bank financial distress in Nigeria from 1986 to 2018 using the ARDL framework. The study differs from previous studies by using the Newey-West estimation approach, which adjusts the standard error process to obtain robust empirical results even when serial correlation or heteroskedasticity or both are present in the model. To our knowledge, this estimation procedure has not been used previously in the context of Nigeria.

The remainder of this study has the following structure: The next section focuses on both theoretical and empirical review, section 3 discusses the data, variables and empirical strategy, section 4 contains the empirical analysis and discussion, and section 5 concludes the study.

\section{Literature Review}

\subsection{Theoretical Considerations}

The buffer theory of Calem and Rob [10] envisage that a bank reaching the regulatory minimum capital ratio may have a reason to boost capital and reduce risk in order to escape the regulatory costs prompted by a violation of the capital requirement.

The main purpose of ensuring that bank capital is sufficient is to enable banks assimilate monetary and macroeconomic shocks which their operation is extremely sensitive to. However, banks may prefer to hold a buffer of excess capital to reduce the probability of falling under the legal capital requirements, especially if their capital adequacy ratio is very risky. Recently, capital adequacy has gone beyond that of banking supervisory instrument to a monetary policy tool of achieving financial stability.

\subsection{Empirical Review}

Buehler et al [9] employ a logistic regression framework to estimate the relationship between capital and leverage ratios on bank distress from 2007 to 2009. Their sample includes 115 large global banks whose combined assets are about $85 \%$ of total banking assets of developed countries and approximately $65 \%$ of global banking assets. Their results provide evidence that capital and leverage ratios are predictors of bank distress. However, tangible common equity to risk-weighted assets ratio is found to be the strongest factor for predicting future bank distress.

In US, Mayes and Stremmel [15] examine the determinants of bank distress and failure as well as compare the performance of risk weighted capital adequacy measures and simple measures of capital adequacy using two different estimation methods: namely, logistics regression and discrete survival time analysis. Their sample comprises quarterly data collected from FDIC-insured banks covering from 1992 to 2012. Their models incorporate both bank-specific CAMELS indicators and macroeconomic condition. They find amongst others that despite being the focus in BASEL framework, risk-weighted capital adequacy measures do not perform better than a simple leverage ratio as the latter explains bank distress and failure more accurately.

Kcharem [13] study the impact of Basel III capital requirements on the financial sector and the real economy. The study tried to identify the reasons for regulating banks and introduced the two previous Basel Accords. The study concluded that Basel III capital requirements are still not enough to keep abreast of continuous banking and financial developments. In addition, the study concluded that the implementation of the new regulatory framework will have both negative and positive repercussions for market participants.

Yousef et al [21] test the impact of Basel III regulation on profitability of banks and loan pricing in the United Arab Emirate (UAE). The result of their tests indicates that the implementation of Basel III will decrease banks' profitability. The result also finds that Basel III regulation will lead to a higher loan pricing in UAE.

Kinyariro et al [14] investigate the relationship between adherence to Basel III accord and financial distress status of commercial banks in Kenya and find that capital, leverage, and liquidity requirements have a positive relationship with financial distress status of commercial banks in Kenya. Hence, they concluded that Basel III accord requirements positively influence the financial distress of commercial banks in Kenya.

Chiaramonte and Casu [11] employ different variants of pooled logistic regression model to investigate the impact of BASEL III structural liquidity and capital ratios on the probability of banks' failure using data obtained at yearly frequency from 28-member states of the European Union from 2004 to 2013. The total number of pooled observations included in their sample with 1,982 involving 513 banks. Their results show that the effect of capital ratios on the probability of banks' failure and distress is more pronounced only for larger banks.

Amahalu et al [4] analyze the effect of capital adequacy on bank financial performance in Nigeria using a panel sample of 14 deposit money banks from 2010 - 2015. The results from fixed effects regression show amongst others that capital adequacy exerts a statistically significant effect on bank financial performance.

Bitar et al [8] employ an OLS regression framework to investigate the effect of higher capital ratios on risk reduction, efficiency and profitability of 1,992 banks 
operating in 39 OECD countries from 1999 to 2013. They find that while both risk-based capital ratios and simple capital ratios enhance bank efficiency and profitability, there is no significant effect of risk-based capital ratios on bank risk. Their results, which hold across different subsamples, alternative measures of risk, efficiency and profitability as well as different estimation methods, also suggest that higher capital ratios may have an adverse effect on the efficiency and profitability of highly liquid banks.

Altunbas et al [3] employ the panel GMM estimation technique to examine the impact of macroprudential policies on bank risk. They use a large panel dataset comprising 20870 bank-date observations for 3177 banks headquartered in 61 emerging and advanced countries for the period from 1990 to 2012. They find that macroprudential polices have a significant effect on bank risk, and that holding bank-specific characteristics constant, macroprudential policies have more impact in a tightening than in an easing episode. Their findings also indicate that there are differences in banks' responses to changes in macroprudential policies, with small and weakly capitalized banks with a higher share of wholesale funding responding more strongly to macroprudential policy changes.

Focusing on Pakistani banking sector, Ashraf and Butt [6] consider effects of both bank-specific factors and macroeconomic variables on non-performing loans within the panel data methodological framework using the random effect model. The study examines three bank-specific factors: namely, credit risk, bank size and capital adequacy ratio and two macroeconomic variables: namely, gross domestic product and inflation. The sample covers the period from 2010 to 2016. They find that capital adequacy ratio, bank size, GDP growth rate and inflation all have a negative effect on non-performing loans (NPL) ratio.

\section{Research Methodology}

\subsection{Data and Variables}

Our data consist of yearly aggregate time series observations from 1986 to 2018. The data obtained from different versions of Central Bank of Nigeria, Nigeria Deposit Insurance Corporation and the fact sheet of the Nigerian Stock Exchange. For reliable empirical analysis, we remove data extremes and outliers through logtransformation. The data analysis is aided by EViews 11 .

The study variables are defined as follows:

Ratio of Distressed Banks (RDB): This is the number of distressed banks to healthy banks in the financial system. A bank is distressed when the ratio of its non-performing loans to total loans falls above the acceptable standard and has one of the highest deciles of the industry using a three (3) year moving average.

Credit to Risk-Weighted Assets Ratio (CRWAR): Credit to risk-weighted assets ratio measures a bank's financial stability by measuring its available capital as a percentage of its risk weighted credit exposure. Risk weighted assets are calculated by looking at a bank's loans, evaluating the risk and then assigning a weight. When measuring credit exposures, adjustments are made to the value of assets listed on a lenders balance sheet. All the loans issued by banks are weighted based on their degree of credit risk.

Capital to Total Assets Ratio (CTAR): This is the ratio of banks capital and reserves to total assets. Capital and reserves include fund contributed by owners, retained earnings, general and special reserves, provisions, and valuation adjustments. Capital to total assets determines whether there is enough capital to cover the assets. It is useful to regulators, business managers and investors.

Asset to Capital Ratio (ACR): This is to determine whether there is enough capital to cover the assets expressed as percentage. Assets to capital ratio is also referred to as TAC multiples. It is a regulatory limit on banks leverage placed on Nigeria's financial institution regulated by the Central bank of Nigeria.

Table 1 shows the descriptive summaries of the variables while their time series plots is shown in Figure 1.

Table 1. Descriptive Statistics for RDB, CRWAR, CTAR and ACR.

\begin{tabular}{lllll}
\hline Variable & $\overline{\boldsymbol{x}}$ & $\boldsymbol{\sigma}$ & $\boldsymbol{S}$ & $\boldsymbol{k}$ \\
\hline RDB & 19.95 & 19.64 & 1.85 & 5.00 \\
CRWAR & 16.25 & 3.64 & -1.34 & 5.93 \\
CTAR & 16.74 & 2.52 & 0.10 & 3.68 \\
ACR & 16.37 & 2.89 & -0.13 & 3.31 \\
\hline
\end{tabular}

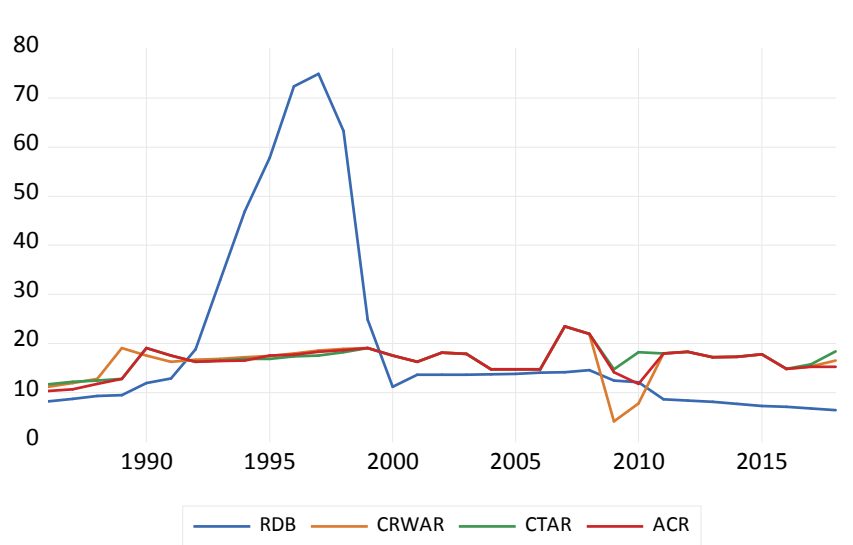

Figure 1. Time series Plot for RDB, CRWAR, CTAR and ACR.

From Table 1, we can see that over the sampled period (1986 - 2018), ratio of distressed banks averaged 19.95 ( $\sigma=19.64$ ) with high variability, while the average values of credit to risk weighted asset ratio, capital to total asset ratio and asset to capital ratio respectively stood at $16.25 \%$, $16.74 \%(\sigma=3.64),(\sigma=2.52)$ and $16.37 \%(\sigma=2.89)$ with much lower standard deviations. Further, while both ratio of distressed banks $(S=1.85)$ and capital to total asset ratio $(S=0.10)$ have a positive skewness coefficient, both credit to risk-weighted asset ratio $(S=-1.34)$ and asset to capital ratio $(S=-0.13)$ have a negative skewness coefficient. On the other hand, the Kurtosis coefficient is higher than 3 for all the variables, indicating that none of the variables may have a normally distributed series.

From Figure 1, the time series plot shows that although, 
the four series trended like a random walk, their movements are characterized by break points, indicating that they contain outlying observations. Thus, they are not stationary and would need to be log-transformed to minimize the negative impact of the observed outliers on the empirical results.

\subsection{Methods and Models}

To analyze the impact of BASEL capital adequacy regulation on financial distress resolution, we employ the ARDL (Autoregressive Distributive Lag) framework. This framework is employed partly because of its dynamic nature and partly because of its known advantage of allowing time series variables with mixed integration in a single empirical model.

The simple ARDL parameterizations of the above models are given as follows:

$$
R D B_{t}=\beta_{0}+\beta_{1} N P L_{t-1}+\beta_{2} C R W A R_{t}+\beta_{3} C R W A R_{t-1}+\beta_{4} C T A R_{t}+\beta_{5} C T A R_{t-1}+\beta_{6} A C R_{t}+\beta_{7} A C R_{t-1}+\varepsilon_{t}
$$

Where; $\beta_{0}$ is the intercept term, $\beta_{1}$ is the autoregressive coefficient which captures the effect of lagged ratio of distressed banks, and $\epsilon_{t}$ is the error term. Also, while $\beta_{2}, \beta_{4}$ and $\beta_{6}$ are the contemporaneous coefficients for capital adequacy ratios, $\beta_{3}, \beta_{5}$ and $\beta_{7}$ are their distributive or lagged coefficients.

Although, our specification includes one lagged term for both the dependent variable and each of the explanatory variables, it is conventional to determine the appropriate lag order empirically. To this end, we employ the popular Schwarz information criterion (SIC) for optimum lag specification.

\section{Empirical Results and Discussion}

\subsection{Results}

Tables 2 and 3 present the regression results and diagnostic tests for the effects of capital adequacy regulation variables on ratio of distressed banks. While the Schwarz Information Criterion (SIC) is used to select the optimum lag order (which selects the model that corresponds to its minimum value), the estimation is based on Newey and West's [17] robust standard errors which are consistent in the presence of unknown heteroskedasticity and serial correlation. Figure 2 presents the SIC model selection results. Figure 3 presents the graph of the regression residuals.

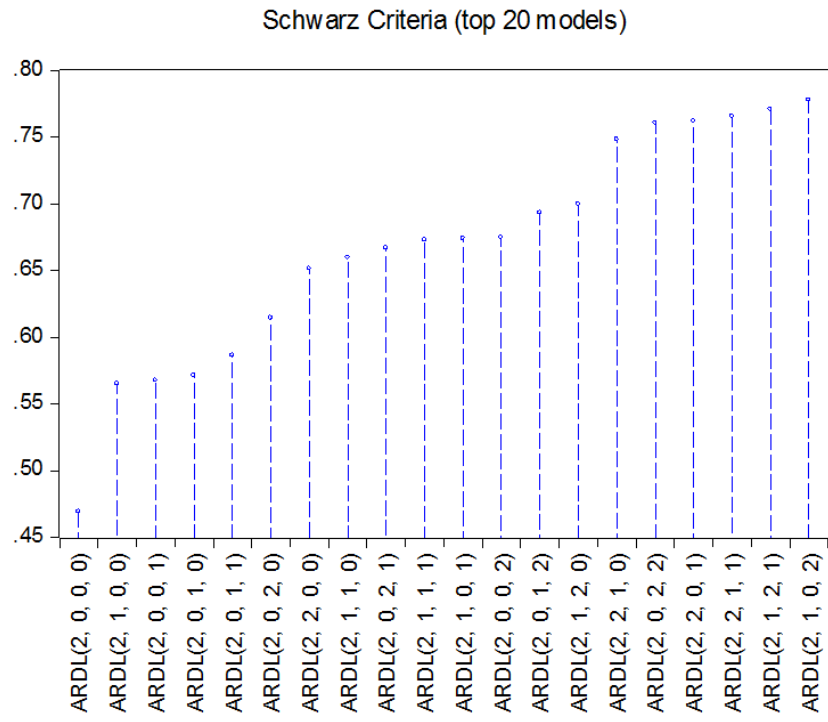

Figure 2. SIC lag selection for plausible specification.
Table 2. Estimation Results; $D V=R D B_{t}$

\begin{tabular}{lll}
\hline Variable & Coefficient & P-value \\
\hline RDB(-1) & 1.4923 & 0.0000 \\
RDB(-2) & -0.6080 & 0.0094 \\
CRWAR & 0.0873 & 0.3638 \\
CTAR & -0.1495 & 0.7432 \\
ACR & -0.0601 & 0.8902 \\
Intercept Term & 0.6592 & 0.4014 \\
Wald (Joint) & 5.4873 & 0.3593 \\
\hline
\end{tabular}

Table 3. Diagnostics and Goodness of Fit Tests.

\begin{tabular}{ll}
\hline Statistic & Value \\
\hline$R^{2}$ & 0.9061 \\
$\bar{R}^{2}$ & 0.8874 \\
F-statistic & 48.303 \\
Prob(F-statistic) & 0.0000 \\
Durbin-Watson & 1.9503 \\
\hline
\end{tabular}

From Figure 2, we can see that the Schwarz information criterion prefers an ARDL (2, 0, 0,0) specification, which implies a model with two lagged values of the dependent variable as additional explanatory variables. Thus, RDB (-1) and $\mathrm{RDB}(-2)$ both must be controlled in our regression if reliable empirical results are desired.

From Table 2, the coefficients on $R D B(-1)$ and $R D B(-2)$ are estimated at 1.4923 and -0.6080 with attached p-values of 0.0000 and 0.0363 , indicating that the additional regressors are statistically significant. The estimated autoregressive coefficients show that, ceteris paribus, a $1 \%$ increase in ratio of distressed banks in the current year would, on average, lead to approximately $1.49 \%$ increase in its next period value, and approximately $0.61 \%$ decrease in its next two period's value. Thus, the net own effect is $0.8843(=1.4923-0.6080)$, which is quite substantial, hence has policy implication. This suggests that a bank that is weak or unable to meet its set goals and targets in the current period will also be unable to meet its goals and targets in the next two years, but the magnitude of the distress would be much lower in the second year.

Further, the regression results show that ratio of distressed banks has only a contemporaneous relationship with credit to risk weighted assets ratio, capital to total assets ratio and assets to capital ratio. The contemporaneous coefficients of $0.0873,-0.1495$ and -0.0601 show that while ratio of distressed banks has a positive relationship with credit to risk weighted assets ratio, it has a negative relationship with both capital to total assets ratio and assets to capital ratio. Specifically, ceteris paribus, ratio of distressed banks would, on average, increase by 
approximately $0.08 \%$ following a $1 \%$ increase in credit to risk weighted assets ratio, but would decrease by approximately $0.15 \%$ and $0.06 \%$ following a $1 \%$ increase in capital to total assets ratio and assets to capital ratio respectively. Thus, the magnitude of the effect of capital to total assets ratio is much higher than that of credit to risk weighted assets ratio as well as assets to capital ratio. However, the p-values of $0.3372,0.7073$ and 0.8658 indicate that none of these explanatory variables enters the ratio of distressed banks model significantly in statistical sense.

Furthermore, the Wald statistic in Table 2 is associated with a p-value of 0.3593 , indicating that the joint test is not statistically significant at all conventional levels. Thus, credit to risk weighted assets ratio, capital to total assets ratio and assets to capital ratio all have no significant effect on ratio of distressed banks, both individually and jointly.

From Table 3, we can see that our optimum ARDL regression model has a good fit $\left(\bar{R}^{2}=0.8874\right)$, with the explanatory factors contributing approximately $89 \%$ of the observed variation in ratio of distressed banks. The associated probability of F-statistic is 0.0000 , which is quite low indicating that the overall regression is highly significant. Also, the value of Durbin-Watson statistic (DW $=1.9503)$ is very much close to 2 , which implies that our model is free from specification errors, hence our empirical results are not spurious and are reliable. This is also confirmed by the residual plot in Figure 3 which shows that the fitted line is close to the actual, and the estimated errors are stationary.

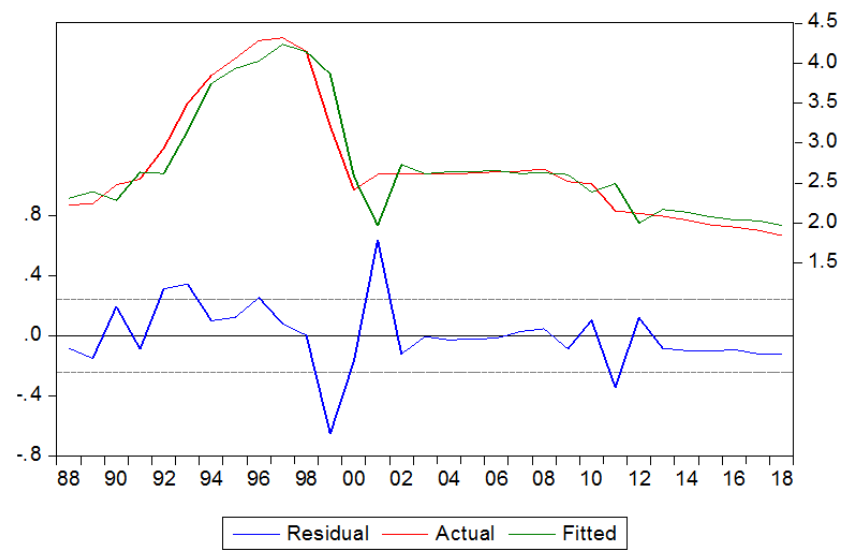

Figure 3. Residual Plot.

\subsection{Discussion of Findings}

The main objective of this study is to determine the extent to which capital adequacy regulation affect ratio of distressed banks in Nigeria. Here, capital adequacy regulation is measured by the joint significance of credit to risk weighted assets ratio, capital to total assets ratio and assets to capital ratio. Bank capital adequacy regulation is a mechanism used to manage or prevent bank failures, hence, it is aimed at minimizing social costs associated with bank insolvency [1, 20]. This implies that capital adequacy regulation can significantly affect ratio of distressed banks. Thus, our apriori expectation is that the Wald statistic, which tests the joint significance of credit to risk weighted assets ratio, capital to total assets ratio and assets to capital ratio, is statistically significant.

Contrary to our expectation, apriori, our results show that controlling for two lagged values of ratio of distressed banks, capital adequacy regulation has no significant effect on ratio of distressed banks. This implies that capital adequacy measures such as credit to risk weighted assets ratio, capital to total assets ratio and assets to capital ratio do not contain relevant information for predicting bank distress in Nigeria. This evidence, which also suggests that banks' distress is unrelated to their capital requirements, disagrees with the general consensus that bank capital adequacy regulation is aimed at preventing financial distress or managing the social cost of financial crisis. This finding is also not in agreement with Barrell et al [7], who find that higher capital adequacy ratio reduces the probability of bank crisis, and Amahalu et al [4], who find that capital adequacy has a significant effect on bank financial performance.

This finding can also be interpreted in the context of Modigliani and Miller's [16] theory, which contends that a firm's source of financing has nothing to do with its value. Hence, the finding tends to be consistent with our initial finding that bank-specific factors play no significant role in bank distress model. Therefore, there is strong support for the view that rather than idiosyncratic factors, bank distress is more explained by contagion effects and/or systemic risks arising from macroeconomic shocks.

\section{Conclusion}

This study investigates the impact of capital adequacy regulation on financial distress resolution in Nigeria using the ARDL framework. Three measures of capital adequacy regulation (credit to risk weighted assets ratio, capital to total assets ratio and assets to capital ratio) are examined, while the dependent variable is ratio of distressed banks. The empirical analysis is based on aggregate data obtained at yearly frequency and covering the period from 1986 to 2018 . The main conclusions are as follows:

There is evidence that financial distress resolution exhibits persistence behavior and depends on its two lagged values, but with a positive and sizable net own effect. However, the relationship between financial distress resolution and capital adequacy regulation measures has no lagged effect. Besides, none of the three capital adequacy ratios is related to ratio of distressed banks in a statistically significant way, and their joint impact is also not statistically significant. Therefore, our results show that capital adequacy regulation is not an important determinant of financial distress resolution in Nigeria, and that the regime of risk-based capital regulation may produce further moral hazards behavior in the Nigerian banking sector. 


\section{References}

[1] Acharya, V. V. (2003). Is the international convergence of capital adequacy regulation desirable?. The Journal of Finance, 58 (6), 2745-2782.

[2] Adeyemi, B. (2011). Bank failure in Nigeria: a consequence of capital inadequacy, lack of transparency and non-performing loans. Banks and bank system. 6 (1), 99-109.

[3] Altunbas, Y., Binici, M., \& Gambacorta, L. (2018). Macroprudential policy and bank risk. Journal of International Money and Finance, 81 (5), 203-220.

[4] Amahalu, N., Okoye, E. I., Nweze, C., Chinyere, O., \& Christian, O. (2017, July). Effect of capital adequacy on financial performance of quoted deposit money banks in Nigeria.

[5] In Chapter 57 in the proceedings of the 2017 International Conference on African Entrepreneurship and Innovation for Sustainable Development (AEISD).

[6] Ashraf, N., \& Butt, Q. U. A. (2019). Macroeconomic and Idiosyncratic Factors of Non-Performing Loans: Evidence from Pakistan's Banking Sector. Journal of Finance and Accounting Research, 1 (2), 44-71.

[7] Barrell, R., Davis, E. P., Karim, D., \& Liadze, I. (2010). Bank regulation, property prices and early warning systems for banking crises in OECD countries. Journal of Banking \& Finance, 34 (9), 2255-2264.

[8] Bitar, M., Pukthuanthong, K., \& Walker, T. (2018). The effect of capital ratios on the risk, efficiency and profitability of banks: Evidence from OECD countries. Journal of International Financial Markets, Institutions and Money, 53, 227-262.

[9] Buehler, K., Samandari, H., \& Mazingo, C. (2009). Capital ratios and financial distress: lessons from the crisis (No. 15). Working Paper.

[10] Calem, P., \& Rob, R. (1999). The impact of capital-based regulation on bank risk taking. Journal of Financial Intermediation, 8 (4), 317-352.

[11] Chiaramonte, L., \& Casu, B. (2017). Capital and liquidity ratios and financial distress. Evidence from the European banking industry. The British Accounting Review, 49 (2), 138161.

[12] Glaessner, T., \& Mas, I. (1995). Incentives and the resolution of bank distress. The World Bank Research Observer, 10 (1), 53-73.

[13] Kcharem, N. (2014). Analysis of Basel III capital requirements repercussions on the financial sector and the real economy. Unpublished MSc. Thesis. Aarhus University.

[14] Kinyariro, D. K., Meeme, M. M., Maina, J. N., \& Muriithi, M. J. (2016). Implications of Basel III accord adherence on financial distress status of commercial banks in Kenya.

[15] Mayes, D. G., \& Stremmel, H. (2014). The effectiveness of capital adequacy measures in predicting bank distress: SUERF Study 2014/1. Brussels: Larcier.

[16] Modigliani, F., \& Miller, M. H. (1958). The cost of capital, corporation finance and the theory of investment. The American economic review, 48 (3), 261-297.

[17] Newey, W. K., \& West, K. D. (1987). Hypothesis Testing with Efficient Method of Moment Estimation? International Economic Review, 28 (3), 777-787.

[18] Olukotun, G. A., \& James, O. O. (2013). Bank distress in Nigeria and the Nigeria deposit insurance corporation intervention. Global Journal of Management and Business Research, 13 (8), 1-11.

[19] Sharpe, W. F. (1977). Bank capital adequacy, deposit insurance and security values, part I (No. w0209). National Bureau of Economic Research.

[20] Weber, R. F. (2010). New governance, financial regulation, and challenges to legitimacy: The example of the internal models approach to capital adequacy regulation. Administrative Law Review, 7 (2), 783-869.

[21] Yousef. P., Mohammed, M. O, and Nayyereh. J. (2015). The impact of Basel III regulation on profitability of banks and loan pricing in the United Arab Emirate. Elkasia Journal of Finance and Risk Management, 6 (1), 167-181. 